\title{
Species composition of understory vegetation in coal mined land in Central Bengkulu, Indonesia
}

\author{
WIRYONO \\ Department of Forestry, Faculty of Agriculture, University of Bengkulu. Jl. Raya Kandang Limun, Bengkulu 38371A, Bengkulu, Indonesia. \\ Tel.: +62-736-21170; Fax.: +62-736-21290; ’email: wiryonogood@yahoo.com.
}

Manuscript received: 28 February 2013. Revision accepted: 26 April 2013.

\begin{abstract}
Wiryono, Siahaan AB. 2013. Species composition of understory vegetation in coal mined land in Central Bengkulu, Indonesia. Biodiversitas 14: 31-36. Coal strip mining in forest area has destroyed forest ecosystem and created barren land. Reclamation of mined land is done by revegetating the land. In addition to planted species, pioneer species usually grow naturally in mined land. The objectives of this study were to know the species composition of understory vegetation growing naturally in coal mined land planted with Gmelina arborea in Central Bengkulu, Indonesia, and to compare that composition with that of unreclaimed coal mined land and of natural forests. Data were collected by sampling understory vegetation in study site. Each plant was identified, harvested and oven-dried to find the biomass. Results showed that the reclaimed mined land had 16 understory species from 6 families, and the abandoned mined land had 10 species from 3 families, lower than that of natural forests, which were 92 and 112. The three most important species were Scleria sumatrensis Retz, Eragrostis chariis (Schult.) Hitchc and Paspalum conjugatum Berg. The species composition of understory vegetation in reclaimed mined land had high similarity with that of abandoned mined land but was totally different from that of natural forests.
\end{abstract}

Key words: Coal mined land, understory, species diversity

\section{INTRODUCTION}

Coal is one of fossil fuels widely used in Indonesia. Coal strip mining commonly conducted in forest area in Indonesia has destroyed the natural forest and created barren land. In general, mined soils have physical, chemical and biological problems that may inhibit optimal plant growth (Bradshaw 1997; Lottermoser 2010). The use of heavy machinery and the high content of rock have resulted in highly compacted soil material, impeding root penetration (Bussler et al. 1984). Chemically, many mined lands have low $\mathrm{pH}$, leading to the increase of soluble iron, aluminum and zinc ions that may cause toxicity to plants. Mined land has low organic matter and soil organisms (Gould and Liberta 1981). Efforts have been done to overcome this low fertility. Physically, soil compaction can be reduced by ripping, tilling, or contouring to improve aeration and infiltration (Ashby 1997; Jacinthe and Lal 2007). Chemically, soil acidity is alleviated by liming (Bradshaw 1997). Biologically, mined land may be introduced with mycorrhiza (Cordell et al. 1999), Rhizobium (Widyati 2007) or earthworms (Vimmerstedt and Finey 1973; Nurliana and Wiryono 2004).

Naturally, succession will bring back the composition of vegetation of mined land into its original one, but it takes very long time. In Western Australia, Norman et al. (2006) found that vegetation composition of mined land had not reached the original state after it had been revegetated for 14 years. Chaffey and Grant (2000) found similar situation in Tomago, New South Wales, Australia. Previous studies in North America also showed the slow process of succession in mined land (Glen-Lewin 1979; Jonescu 1979).

To speed up the succession, deliberate restorations of mined land have been done. Restoration of degraded land may be viewed as reconstruction of original ecosystem (Cooke and Johnson 2002), but there is an argument whether this is desirable or possible due to the dynamic nature of ecosystem and the irrevesibility of some changes that might have happened (Hobbs and Harris 2001). Revegetation of mined land is an early step to bring back the original ecosystem. However, due to the low soil fertility of the land, the species planted are usually the pioneer ones which can grow in harsh condition. In Sumatra, several pioneer species have been successfully planted in mined land such as Paraserianthes falcataria, Leucaena leucocephala, Sesbania grandiflora, and Acacia mangium (Munawar 2003; Nurliana and Wiryono 2004; Suhartoyo et al. 2012). Several pioneer shrub species have been used to improve soil chemical, physical and biological properties of mined land in Bengkulu (Prawito 2009). Litter from pioneer vegetation can improve soil nutrient for plants in mined land (Munawar et al. 2011).

In addition to planted species, some pioneer species naturally invade the area. Both the planted and naturally invading species will undergo succession and the 
community will finally reach the climax. Community structure and species composition are some factors to be considered in determining the success of ecosystem restoration (Tongway and Ludwig 2006; Cooke and Johnson 2002). The objectives of this research were to know the species composition of understory $(\mathrm{Br}$ : understorey) plants growing naturally in coal mined land recently revegetated with Gmelina arborea in Central Bengkulu, Indonesia, and to compare it with that of abandoned or unrevegetated coal mined land and of natural forests.

\section{MATERIALS AND METHODS}

\section{Site and time}

This research was done in coal mining area of Danau Mas Hitam Company in Taba Penanjung Sub District, Central Bengkulu District, Bengkulu Province (Figure 1), Indonesia, in May-July 2008. Before mining the site used to be hill forest in the Bukit Barisan Mountain range, with altitudes of 300-500 $\mathrm{m}$ above sea level. It has wet climate with an average annual rainfall approximately $3,000 \mathrm{~mm}$.

\section{Sampling}

Samplings of ground cover vegetation and soil were done in two types of mined lands, namely the reclaimed land planted with Gmelina arborea 1.5 years before the sampling and one abandoned (un-reclaimed) mined land. The reclaimed mined land was introduced with mycorrhiza and Rhizobium by another researcher. This revegetated land consisted of two sites having different soil colors. The first site was strong brown (7.5 YR 4/6 in Munsell soil color charts) and the other was black (5Y 2.5/1). The abandoned land had dark yellowish brown (10 YR 3/4) soil materials. We did not investigate the cause of color differences among sites.

Samplings of vegetation were done in $1 \times 1 \mathrm{~m}$ plots with $25 \%$ sampling intensity. The number of sample plots in strong brown reclaimed soils was 63 , in black reclaimed soil 72 and in abandoned mined soil 135. The plots were placed systematically with random start.

For every plot, each species of understory plants consisting of herbs and shrubs less than $2 \mathrm{~m}$ in height were recorded, harvested and placed in paper bags. Harvest method was used because this method can give better quantitative data than percent coverage method. The bags were then oven-dried at a temperature of $105^{\circ} \mathrm{C}$ for 24 hours or more until the weight was constant. For identification, a specimen of herbarium was taken for each species. These specimens were oven-dried at a temperature of $80^{\circ} \mathrm{C}$ for 8 hours.

A composite soil sample was taken from each land type. The soil samples were then dried and taken to Soil Laboratory in the Faculty of Agriculture, the University of Bengkulu, for chemical and physical analyses. Chemical analyses were done to find out the $\mathrm{pH}$, and nitrogen, phosphor, and potassium content. Physical analyses were done to determine the soil porosity.

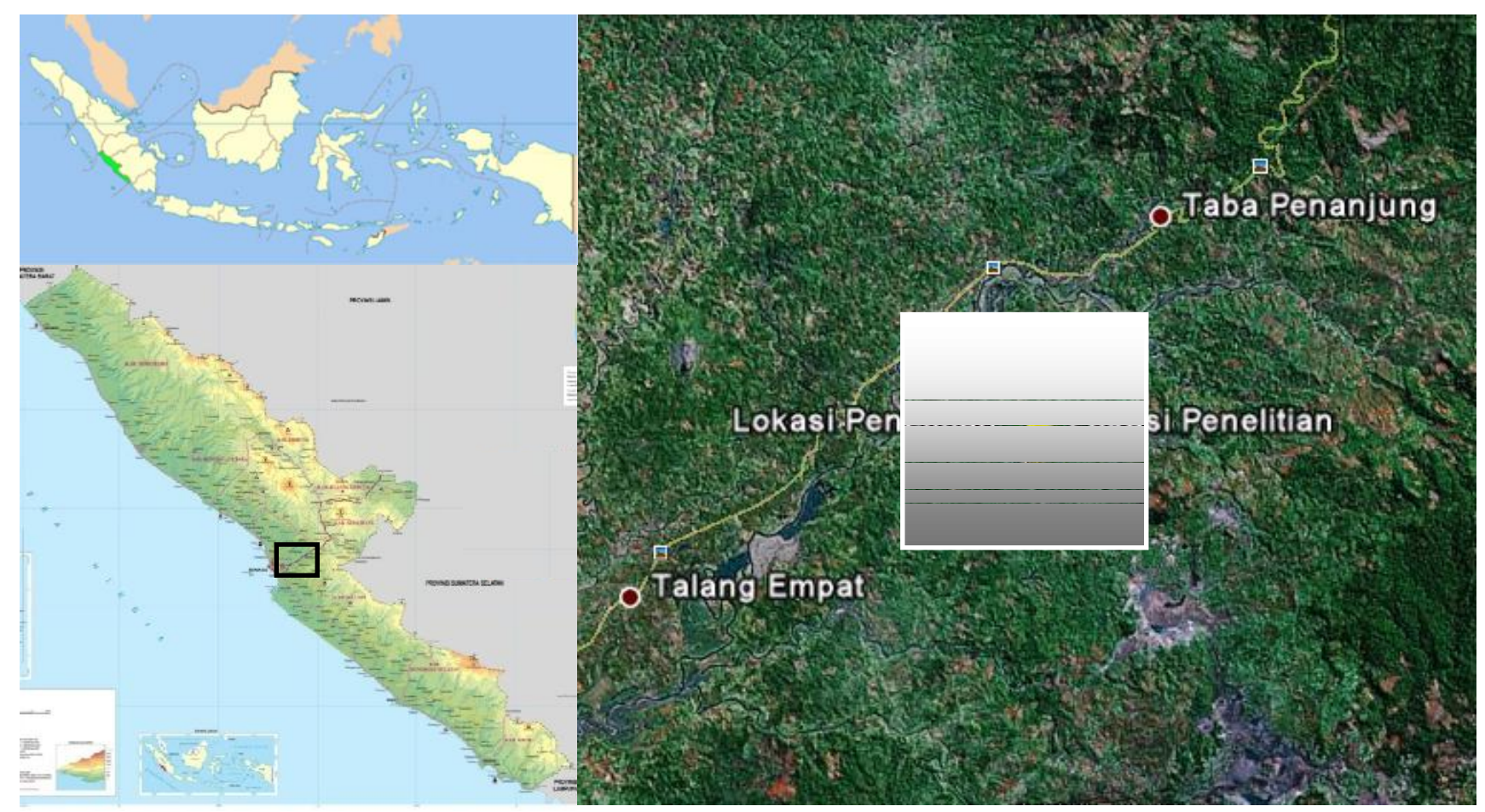

Figure 1. Location of study (yellow mark), in the Sub-district of Taba Penanjung, Central Bengkulu District, Bengkulu Province, Indonesia. 


\section{Data analyses}

Plant species identification was conducted in the Herbarium of Forestry Department, University of Bengkulu, using several field guides (Soerjani et al. 1987; Sastrapradja and Afriastini 1980, 1981; Hafliger and Scholz 1980, 1981; Hafliger et al. 1982).

Species importance was determined by biomass, because clumped grasses and creeping plants constituted a large portion of understory plants in the study site. It is not possible to count individual stem of grasses in clumps and of creeping plants. According to Whittaker (1975) species importance in a community can be determined by several quantitative measurements, one of which is biomass. This study did not use percent coverage method, because visual estimate of coverage would give less accurate data than actual weighing of the biomass.

Biomass for each plant, calculated using the formula in Brower et al. (1998):

$$
\begin{aligned}
& \mathrm{Bi}=\frac{\sum W i}{A} \\
& \mathrm{Bi}=\text { Biomass of } \mathrm{i} \text { species }\left(\mathrm{g} \cdot \mathrm{m}^{-2}\right) \\
& \Sigma W \mathrm{i}=\text { Dry weight of all individuals of i species }(\mathrm{g}) \\
& \mathrm{A} \quad=\text { Area sampled }\left(\mathrm{m}^{2}\right)
\end{aligned}
$$

To compare the composition of each land, Sørensen Index of Similarity was calculated (Mueller-Dombois and Ellenberg 1974).

\section{Sørensen Index:}

$$
\mathrm{IS}_{\mathrm{S}}=\frac{2 c}{A+B} \times 100 \%
$$

$\mathrm{A}=$ the number of all species found in in A community

$\mathrm{B}=$ the number of all species found in $\mathrm{B}$ community

$\mathrm{c}=$ the number of common species (found in both $\mathrm{A}$ and $\mathrm{B}$ )

Data of understory plants of natural forest were taken from the theses of Loanita (1999) in Bukit Kaba, Kepahiang District and Setiawan (1998) Lebong Selatan, Lebong District, both in Bengkulu Province, within the radius of $50 \mathrm{~km}$.

\section{RESULTS AND DISCUSSION}

\section{Species composition}

The understory vegetation in mined land was composed of 17 species, from 7 families. The black reclaimed soil had the highest number of species, 16, while the dark brown reclaimed soil had only 11 species, almost the same with the non reclaimed land which had 10 species (Table 1; Figure 2). The number of species in this mined land was higher than 4-year old vegetation in another mined in Muara Enim, South Sumatra, which was only 10 (Suhartoyo et al. 2012). The species richness of this mined land was much lower than those in natural forests in Bengkulu, which were 92 in Bukit Kaba (Loanita 1999) and 112 in Lebong Selatan Sub District (Setiawan, 1998). In this present study, species diversity index was not determined because it is not possible to count the number of plants of clumped grasses and creeping plants. Number of species is the simplest measurement of species diversity (Whittaker, 1975). Colinvaux (1986) even believed that

\begin{tabular}{|c|c|c|c|c|}
\hline Species & Family & A1 & A2 & $\mathbf{B}$ \\
\hline Chromolaena odorata $(\mathrm{L})$. & Asteraceae & + & + & + \\
\hline \multicolumn{5}{|l|}{ R.M.King \& H.Robinson } \\
\hline Mikania micrantha H.B.K. & Asteraceae & + & + & + \\
\hline Wedelia trilobata $\mathrm{L}$ & Asteraceae & + & + & - \\
\hline Porophyllum ruderale (Jacq.) Cass. & Asteraceae & - & + & + \\
\hline Imperata cylindrica (L.) P. Beauv. & Poaceae & + & + & - \\
\hline Paspalum commersonii Lamk. & Poaceae & + & + & + \\
\hline Paspalum conjugatum Berg. & Poaceae & + & + & + \\
\hline Pennisetum sp. & Poaceae & - & - & + \\
\hline Eragrostis chariis (Schult.) Hitchc. & Poaceae & + & + & + \\
\hline Eleusine indica (L.) Gaertn. & Poaceae & + & + & + \\
\hline Pycreus sanguinolentus (Vahl) Nees & Cyperaceae & - & + & + \\
\hline Scleria sumatrensis Retz. & Cyperaceae & + & + & + \\
\hline Fimbristylis miliaceae (L.) Vahl & Cyperaceae & - & + & - \\
\hline Polygala paniculata. L. & Polygalaceae & + & + & - \\
\hline Calopogonium mucunoides Desv. & Fabaceae & - & + & - \\
\hline Hyptis rhomboidea Mart. \& Gal. & Lamiaceae & - & + & \\
\hline Mimosa pudica $\mathrm{L}$ & Fabaceae & + & + & - \\
\hline Number of species & & 11 & 16 & 10 \\
\hline
\end{tabular}
number of species is more meaningful than diversity index.

Table 1. Species composition of understory vegetation in coal mined land of Danau Mas Hitam Company in Taba Penanjung Sub District, Central Bengkulu District.

Note : (+) Present ; (-) Absent; Land A1 = strong brown reclaimed land; Land $\mathrm{A} 2$ = black reclaimed; Land $\mathrm{B}=$ abandoned land. Family: Asteraceae $=$ Compositae, Poaceae $=$ Gramineae Lamiaceae $=$ Labiateae

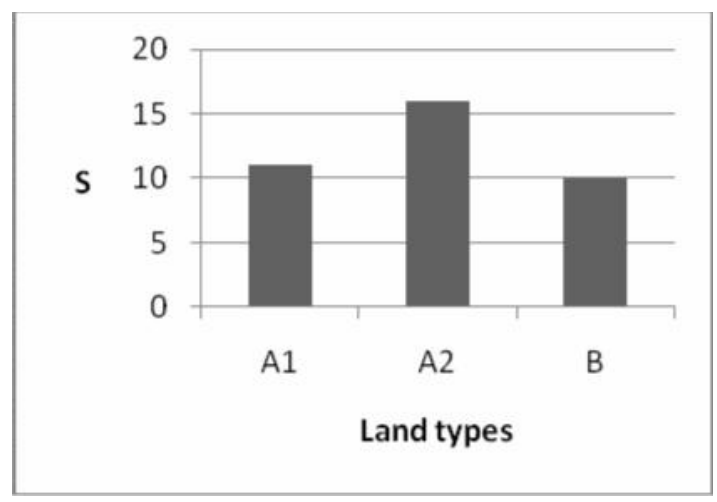

Figure 2. The number of species (S) of understory plant in strong brown reclaimed mined land (A1), black reclaimed mined land (A2) and abandoned mined land (B). 


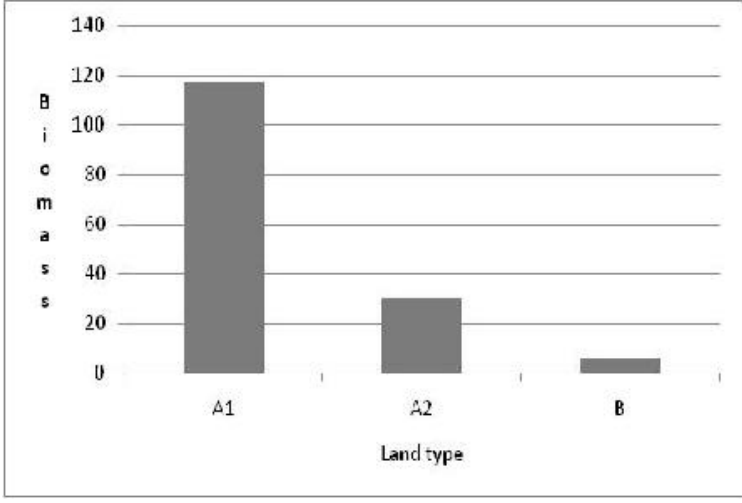

Figure 3. Biomass $\left(\mathrm{g} \cdot \mathrm{m}^{-2}\right)$ of understory vegetation in strong brown reclaimed mined land (A1), black reclaimed mined land (A2) and abandoned mined land.

The low species richness of understory vegetation in mined land was presumably caused by two factors. First, the land was only recently reclaimed or abandoned. In Western Australia, Norman et al. (2006) found that the composition of vegetation in mined land had not matched that of the original vegetation, even after 14 years of reclamation.Similar situation was found in Tomago, New South Wales (Chaffey and Grant 2000). The second factor may be the low fertility of the mined land as shown by soil test results (Table 2), indicating that all sites in general had low soil fertility.

Table 2. Soil $\mathrm{pH}$, nitrogen, phosphorus and potassium content, and porosity

\begin{tabular}{|c|c|c|c|c|c|}
\hline Land types & $\begin{array}{l}\mathrm{pH}- \\
\mathrm{H}_{2} \mathrm{O}\end{array}$ & $\begin{array}{c}\mathrm{N}- \\
\text { total } \\
(\%)\end{array}$ & $\begin{array}{l}\mathbf{P}_{2} \mathbf{O}_{5} \\
(\mathbf{p p m})\end{array}$ & $\begin{array}{c}\mathrm{K}- \\
\text { available } \\
\left(\mathrm{me} .100 \mathrm{~g}^{-1}\right)\end{array}$ & $\begin{array}{c}\text { Total } \\
\text { porosity } \\
(\%)\end{array}$ \\
\hline $\begin{array}{l}\text { brown reclaimed } \\
\text { (A1) }\end{array}$ & & 0.16 & 3.21 & 0.1 & 48.605 \\
\hline $\begin{array}{l}\text { Black reclaimed land } \\
\text { (A2) }\end{array}$ & 4.5 & 0.14 & 4.33 & 0.3 & 45.402 \\
\hline Abandoned land (B) & 4.2 & 0.13 & 5.16 & 0.41 & 46.281 \\
\hline
\end{tabular}

Note: $\mathrm{ppm}=$ part per million, $\mathrm{me}=$ milli equivalent.

\section{Species importance}

Species importance was determined by the biomass. The three most important or dominant species were Scleria sumatrensis, Eragrostis chariis, and Paspalum conjugatum, but they ranked differently in each land type (Table 3 ). In dark brown reclaimed land, the biomass of Scleria sumatrensis and Eragrostis chariis had much higher biomass than the other species. Scleria sumatrensis is a perennial grass, has dense clumps, and may reach $2 \mathrm{~m}$ in height (Nasution 1986). A clump of this species may cover $1 \mathrm{~m}^{2}$ of ground. Eragrostis chariis can grow in compacted stony soil, sandy soil, or clay. It has extensive and deep root system so that it is hard to uproot. It may reach 1.25 in height and it has many leaves near the ground (Sastrapradja and Afriastini 1981). It was obvious that the two grasses were capable of producing large biomass and could therefore dominate the areas.
Table 3. The biomass of understory plants in three types of mined land.

\begin{tabular}{|c|c|c|c|}
\hline \multirow{2}{*}{ Species } & \multicolumn{3}{|c|}{ Biomass $\left(\mathrm{g} . \mathrm{m}^{-2}\right)$} \\
\hline & A1 & A2 & B \\
\hline Scleria sumatrensis Retz. & 92.76 & 7.26 & 1.59 \\
\hline Eragrostis chariis (Schult.) Hitchc. & 19.07 & 2.52 & 1.79 \\
\hline Paspalum conjugatum Berg. & 1.39 & 10.75 & 1.35 \\
\hline $\begin{array}{l}\text { Chromolaena odorata (L.) R.M.King \& } \\
\text { H.Robinson }\end{array}$ & 1.14 & 1.41 & 0.43 \\
\hline Eleusine indica (L.) Gaertn. & 0.02 & 0.02 & 0.02 \\
\hline Mikania micrantha H.B.K. & 0.43 & 0.01 & 0.10 \\
\hline Paspalum commersonii Lamk. & 0.58 & 0.33 & 0.22 \\
\hline Mimosa pudica $\mathrm{L}$. & 1.40 & 0.13 & 0 \\
\hline Wedelia trilobata & 0.11 & 0.27 & 0 \\
\hline Polygala paniculata. L. & 0.06 & 0.28 & 0 \\
\hline Imperata cylindrica (Linn.) P. Beauv. & 0.57 & 0.33 & 0 \\
\hline Fimbristylis miliaceae (L.) Vahl & 0 & 0.44 & 0 \\
\hline Hyptis rhomboidea Mart. \& Gal. & 0 & 0.13 & 0 \\
\hline Calopogonium mucunoides Desv. & 0 & 5.46 & 0 \\
\hline Pycreus sanguinolentus (Vahl) Nees & 0 & 0.22 & 0.46 \\
\hline Porophyllum ruderale (Jacq.) Cass. & 0 & 0.09 & 0.03 \\
\hline Pennisetum sp. & 0 & 0 & 0.09 \\
\hline Total & 117.54 & 29.63 & 6.07 \\
\hline
\end{tabular}

Note: Land $\mathrm{A} 1=$ strong brown reclaimed land; Land $\mathrm{A} 2=$ black reclaimed land; Land $\mathrm{B}=$ abandoned land.

In the black reclaimed soil, Paspalum conjugatum was the most dominant species, with much higher biomass than the other species. This species grows well in open space (Nasution 1986) as in this type of land. This species has strong root system and may reach $50 \mathrm{~cm}$ in height and has 3-5 leaves in each node. It reproduces by seeds as well as by rhizome. Even in hard soil this species thrives (Sastrapradja and Afriastini 1980).

The biomass of reclaimed land was much higher than that of abandoned land (Figure 3). This might be due to the introduction of mycorrhiza and nitrogen fixing bacteria and fertilization in the reclaimed land. Although both the reclaimed and abandoned mined land had low fertility, it is possible that mycorrhiza and Rhizobium which might have infected the roots help the plants take nutrients from the soil. It has been reported the addition of both Rhizobium and mycorrhiza can increase the uptake of nitrogen, phosphorus and potassium by seedlings to be used for rehabilitation of mined land (Widyarti 2007). Reforestation of coal mined land in Ohio was successful due to inoculation of mycorrhiza (Cordell et al. 1999).

\section{Composition similarity}

Sørensen's Index (Table 4) showed that both reclaimed mined had high similarity, which was $81 \%$. This means that the species composition of both areas was relatively the same. Both reclaimed land had moderately high $(63 \%$, and 69\%) similarity index with abandoned mined land. When the composition of each mined land type was compared with that of natural forests in Bukit Kaba (Loanita 1999) and in Lebong Selatan Sub District (Setiawan 1998), the indices showed zero values, meaning that the species composition of understory vegetation in mined land was totally different from that in natural forest. The presence of indigenous species is one of nine criteria 
for the success of restoration set by the Society of Ecological Restoration (Clewel and Aronson 2007). This total difference indicated that mined land and natural forest had different stage of succession. Mined land vegetation was in the early stage of succession while natural forest was in a climax stage, or in late stage of succession. The species colonizing the mined land were pioneer species. Over time, these species will be gradually replaced by late succession species. In South Sumatra, even after 15 years of mined reclamation, the species composition of ground cover was still different from that of the natural forest nearby (Suhartoyo et al. 2012). In Australia, the rehabilitated mined land, age 8-24 years, only had 12-37 species in common with the adjacent natural shrub land (Herath et al. 2009).

Table 4. Species composition similarity of understory vegetation among land types

\begin{tabular}{ll}
\hline Types of land compared & ISs (\%) \\
\hline $\begin{array}{l}\text { Strong brown reclaimed land and black reclaimed } \\
\text { mined land }\end{array}$ & 81.15 \\
$\begin{array}{l}\text { Strong brown reclaimed land and abandoned mined } \\
\text { land }\end{array}$ & 63.64 \\
Black reclaimed land and abandoned mined land & 69.23 \\
Reclaimed mined land and natural forest & 0 \\
Abandoned mined land and natural forest & 0 \\
\hline
\end{tabular}

Note: ISs = SØrensen's Index of Similarity,

\section{Soil properties}

The soil properties (Table 2) in reclaimed and abandoned mined land showed low fertility (Balai Penelitian Tanah 2005). All three sites were very acidic and had low total nitrogen. Potassium levels were low in both reclaimed land and medium in abandoned land. The difference, however, was very little. Phosphorus levels were very low in reclaimed land and low in abandoned land. The porosity was medium for all sites. The sites had low fertility because the soil surface material was not top soil, but mine spoil. The presence of vegetation for one year had not increased soil fertility. Other studies in Sumatra also showed that newly reclaimed coal mined had relatively low soil fertility (Suhartoyo et al. 2012; Munawar 2003; Nurliana and Wiryono 2004). The soil condition in this study site was not extremely harsh; so many species of pioneer plants invaded this site naturally. Some mine sites are so harsh that only few plants can grow unless soil amelioration has been conducted (Bradshaw 1997).

\section{CONCLUSION}

The understory vegetation in coal mined land under 1.5 year-old Gmelina arborea stand was composed of 16 species of plants from 6 families. The abandoned mined land had only 10 species from 3 families. The three most important species were Scleria sumatrensis Retz, Eragrostis chariis (Schult.) Hitchc and Paspalum conjugatum Berg. The biomass of understory vegetation in reclaimed mined land was much higher than that of abandoned mined land. The species composition of two types of reclaimed mined land was similar to each other and to that and abandoned mined land, but totally different from that of natural forests.

\section{ACKNOWLEDGEMENTS}

We thank the management of Danau Mas Hitam Company who allowed us to do research in their concession area. We appreciate the help and suggestion of Guswarni Anwar during our research. The valuable suggestions from an anonymous reviewer are gratefully acknowledged.

\section{REFERENCES}

Ashby WC. 1997. Soil ripping and herbicides enhance tree and shrub restoration on stripmines. Restor Ecol 5:169-177.

Balai Penelitian Tanah. 2005. Chemical analyses for soil, plants, water and fertilizers. Research and Development Agency, The Minstry of Agriculture, Jakarta [Indonesian]

Bradshaw AD. 1997. The importance of soil ecology in restoration science. In Urbanska, KM , Webb NR, Edwards PJ (eds) Restoration ecology and sustainable development. Cambridge University Press, UK.

Brower JE, Zar JH, von Ende CN. 1998. Field and laboratory methods for general ecology. 4th ed. WCB McGraw-Hill. Boston. Massachusetts.

Bussler BH, Byrness WR, Pope PE, Chaney WR. 1984. Properties of minesoil reclaimed for forest land use. Soil Sci Soc Amer J 48:178184.

Chaffey CJ, Grant CD. 2000. Fire management implications of fuel loads and vegetation structure in rehabilitated sand mines near Newcastle, Australia. For Ecol Manag 129:269-278.

Clewel AF, Aronson J. 2007). Ecological restoration. Principles, values and structure of an emerging profession. Island Press, Washington, D.C.

Colinvaux P. 1986. Ecology. John Wiley \& Sons, New York.

Cooke JA, Johnson MS. 2002. Ecological restoration of land with particular reference to the mining of metals, and industrial minerals: A review of theory and practice. Environ Rev 10:41-71.

Cordell CE, Marrs LF, Farley ME. 1999. Mycorrhizal fungi and trees-a successful Reforestation alternative for mine land reclamation. In Vories KC, Throgmorton D (eds) Proceedings of Enhancement of reforestation at surface coal mines: Technical interactive forum. Drawbridge Inn and Conference Center Fort Mitchell, Kentucky March 23-24, 1999. U.S. Department of the Interior, Office of Surface Mining, Coal Research Center, Southern Illinois University, Carbondale, Texas Utilities.

Glen-Lewin DC. 1979. Natural revegetation of acid coal spoils in Southern Iowa. In M.K. Wali (ed) Ecology and coal resources development. Pergamon Press, New York.

Gould AR, Liberta AE. 1981. Effects of storage during surface mining on the viability of vesicular arbuscular mycorrhiza. Mycologia 73:914922.

Hafliger E, Scholz H. 1980. Grass Weeds 1. CIBA-GEIGY. Switzerland.

Hafliger E, Scholz H. 1981. Grass Weeds 2. CIBA-GEIGY. Switzerland.

Hafliger E, Kuhn U, Hame L, Cook, CDK, Faden R, Speta F. 1982. Monocot weeds 3. CIBA-GEIGY. Switzerland.

Herath DN, Lamont BB, Enright NJ, Miller BP. 2009. Comparison of post-mine rehabilitated and natural shrubland communities in Southwestern Australia. Rest Ecol 17 (5): 577-585

Hobbs RJ, Harris JA. 2001. Restoration ecology. Repairing the earth's ecosystem in the new millennium. Rest Ecol 9 (2): 239-246.

Jacinthe, PA, Lal R. 2007. Carbon storage and minesoil properties in relation to topsoil applications techniques. Soil Sci Soc Amer J 71: 1788-1795.

Jonescu, ME. 1979. Natural revegetation of strip-mine land in the lignite and coal fields of Western Saskatchewan. In: Wali MK (ed) Ecology and coal resources development. Pergamon Press, New York. 
Loanita L. 1999. Analysis of understory vegetation of Bukit Kaba hill forest. [Thesis] Department of Forestry, University of Bengkulu, Bengkulu [Indonesian].

Lottermoser BG. 2010. Mine Wastes. Characterization, treatment and environmental impacts. 3rd ed. Springer. Berlin.

Mueller-Dumbois D, Ellenberg H. 1974. Aims and methods in vegetation ecology. John Willey \& Sons, New York.

Munawar A. 2003. Soil fertility levels in coal mined soil in two-year-old stands of Paraserianthes falcataria L. and Sebania grandiflora Pers. Jurnal Lembaga Penelitian Universitas Bengkulu 4 (7):1-5. [Indonesian].

Munawar A, Indramawan, Suhartoyo H. 2011. Litter production and decomposition rate in the Reclaimed Mined Land under Albizia and Sesbania stands and their effects on some soil chemical properties. J Trop Soils (16) 1: 1-6.

Nasution U. 1986. Weeds and their control in rubber plantation in North Sumatra and Aceh. The Center for Research and Development of Plantation at Tanjung Morawa, Medan. [Indonesian].

Norman MA, Koch JM, Grant CD, Morald TK, Ward SC. 2006 Vegetation succession after bauxite mining in Western Australia. Restoration Ecology 14: 278-288.

Nurliana S, Wiryono. 2004. The effects of surface soil treatments on the growth of Sesbania grandiflora and Leucaena leucocephala in coal mined soil. Jurnal Penelitian UNIB 10 (3): 145-149. [Indonesian]
Prawito P. 2009. The use of pioneer species in the rehabilitation process of post mined land in Bengkulu. Jurnal Ilmu Tanah dan Lingkungan 9 (1):7-12. [Indonesian]

Sastrapradja S, Afriastini JJ. 1980. Species of low landgrasses Biologi Nasional. LIPI. Bogor. [Indonesian]

Sastrapradja S, Afriastini JJ. 1981. Species of mountainous grasses. Lembaga Biologi Nasional_LIPI. Bogor. [Indonesian]

Setiawan I. 1998. Analysis of understory vegetation of Kerinci Seblat National Park in Tes, Lebong Selatan Sub-district. [Thesis]. Department of Forestry, University of Bengkulu, Bengkulu.

Soerjani M, Kosterman AJGH, Tjitrosoepomo G. 1987. Weeds of rice in Indonesia. Balai Pustaka. Jakarta.

Suhartoyo H, Munawar A, Wiryono. 2012. Returning biodiversity of rehabilitated forest on a coal mined site at Tanjung Enim, South Sumatra. Biodiverstas 13:13-17.

Tongway DJ, Ludwig JA. 2006. Assessment of landscape function as an information source for mine closure. In A. Fourie A, Tibbet M (eds) Mine Closure. Australian Centre for Geomechanics, Perth.

Vimmerstedt JP, Finney JH. 1973. Impact of earthworm on litter burial and nutrient distribution in Ohio strip mine spoil banks. Soil Sci Soc Amer J 37: 388-393.

Whittaker RH. 1975. Communities and Ecosystems. 2-nd ed. MacMillan Publishing Co. Inc. New York.

Widyati E. 2007. Formulation of microbe inoculums: MA, BPF and Rhizobium from coal mined soil for seedlings of Acacia crassicarpa Cunn. Ex-Benth. Biodiversitas 8 (3): 238-241. 